\title{
ОЦЕНКА ПРОТИВОДИАБЕТИЧЕСКОГО ДЕЙСТВИЯ ПРОИЗВОДНЫХ ГАМК
}

\author{
Д.А. Бакулин, М.А. Дубровина, Е.Е. Абросимова, Д.В. Куркин, \\ И.Н. Тюренков
}

Лаборатория фармакологии сердечно-сосудистых средств НЦИЛС, ВолгГМУ, 400087, Россия, Волгоград, ул. Новороссийская, 39.

DOI: 10.19163/MedChemRussia2021-2021-97

E-mail:mbfdoc@gmail.com

Современные рекомендации по терапии сахарного диабета (СД) сфокусированы не только на установлении эффективного контроля над гликемией, но и на профилактике сосудистых осложнений и улучшении функционального состояния бета-клеток. В последние годы для ГАМК был выявлен ряд панкреопротективных эффектов, что обосновывает поиск среди ее производных веществ потенциальных для комбинированной терапии у пациентов с метаболическими нарушениями в том числе сахарным диабетом 2 типа и/или ожирением [1].

Исследование выполнено на 3 моделях СД: преддиабет вследствие алиментарного ожирения, СД смешанного типа (стрептозотоцин-никотинамид-индуцированный) и СД 1 типа (аллоксановый СД) [2,3]. Производные ГАМК (аминалон 300 мг/кг, пикамилон 200 мг/кг и фенибут 25 мг/кг) вводили курсом, после формирования патологии (СД смешанного типа и СД 2 типа), а также лечебно-профилактически до и после формирования патологии (СД 1 типа). Противодиабетическую активность ГАМК-миметиков оценивали при проведении перорального теста на толерантность к глюкозе после лечения.

Лечебное и профилактическое введение производных ГАМК способствовало снижению тяжести аллоксанового диабета, что выражалось в значимом снижении летальности животных и тенденции к снижению уровня гликемии в группах, получавших аминалон и пикамилон. При курсовом лечебном введении производных ГАМК животным с алиментарным ожирением и стрептозотоцин-никотинамид-индуцированным СД было отмечено значимое ускорение утилизации глюкозы в группе, получавшей аминалон.

Из трех производных ГАМК (аминалон, пикамилон и фенибут) аминалон значимо улучшает утилизацию глюкозы у животных со стрептозотоцин-никотинамид-индуцированным СД и животных с ожирением. Аминалон и пикамилон снижают тяжесть течения аллоксанового СД. Дальнейшие исследования необходимы для выбора гипогликемического препарата для создания рациональной комбинации с ГАМК миметиком.

\section{Литература}

[1] X. Huang, G. Liu, J. Guo, Z. Su, Int J Biol Sci. 2018, 14(11), 1483-1496

[2] И.Н. Тюренков, Д.В. Куркин, Д.А. Бакулин, Е.В. Волотова, Проблемы эндокринологии. 2016, 62(1), 44-49

[3] А.А. Спасов, М.П. Воронкова, Г.Л. Снигур, Н.И. Чепляева, М.В. Чепурнова, Биомедицина. 2011, 3, 12-18. 